$$
\begin{gathered}
\text { 声帯スティフネスの測定 } \\
\text { ーファイバースコープ下吸引法一 } \\
\text { 田中 信三・平野 実 }
\end{gathered}
$$

\title{
Evaluation of Vocal Fold Stiffness with Fiberscopy
}

\author{
Shinzo Tanaka and Minoru Hirano \\ (Kurume University)
}

For the purpose of evaluating the stiffness of the pathological vocal folds in vivo, a fiberscopic device was developed. It consisted of a laryngeal fiberscope and a suction tube connected to the forceps channel of the fiberscope. The tube had a small hole in the side wall and the tip of the tube was closed. The forceps channel was connected to an aspirator, and the vocal fold was sucked vertically under fiberscopic observation using a video recording system. From a pair of video images before and after the vocal fold was sucked in, the suction distance was measured, and the stiffness was calculated.

A normal subject and patients with various laryngeal disorders were examined. The stiffness of the normal vocal fold was 3 to $4 \mathrm{~g} / \mathrm{cm}$. In the cases of laryngeal carcinoma, scarring after laryngeal injury and sulcus vocalis, the stiffness of the lesion was significantly greater than normal. The data suggest that the evaluation of the vocal fold stiffness with a fiberscope is useful in diagnosing the degree and extent of high stiff lesions in the vocal fold.

Key words: stiffness, glottal carcinoma, scar of vocal folds, fiberscopy and sucking method

はじめに

喉頭癌や喉頭外傷後の疲痕では, 病変部のス ティフネス (硬度) が正常の粘膜より増大す る. 従って, 声帯病変のスティフネスを測定す るととは, 喉頭癌や㓔痕の程度と広がりを診断 する上で有用と考えられる。声带スティフネス は, 従来, 声帯粘膜の荷重に対する粘膜の移動 距離1) 3) やダンピング率45) により実験的に測 定されてきたが，声帯病変を in vivo に測定す る事は技術的に困難であった。一色は摘出喉頭
の声帯粘膜を一定の圧で吸引し，粘膜移動性が 大きいほど吸引距離が長いととを示した の実験結果から, 声帯病変を吸引することでス ティフネスが評価できると考え，ファイバース コープと吸引チップを用いて外来診察時に施行 できる声带スティフネスの测定法を開発した. 本論文では吸引によるスティフネスの測定方法 を具体的に論述し，ファイバースコープ下吸引 法による声带スティフネスの測定結果を種々の 喉頭病変について報告する. 


\section{測定方法}

図 1 に測定に用いた装置を示す，鎮子チャン ネル付きファイバースコープ（ペンタックス FNL-K1) の先端に径 $1.6 \mathrm{~mm}$ の吸引チップを 装着し, $400 \mathrm{mmHg}$ の陰圧で持続吸引した。 吸

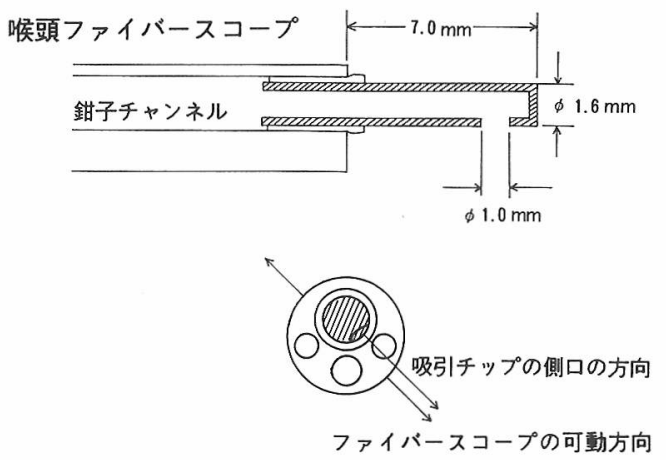

図1ファイバースコープの先端に装着した吸引チッ プ (プラスティック製) の模式図
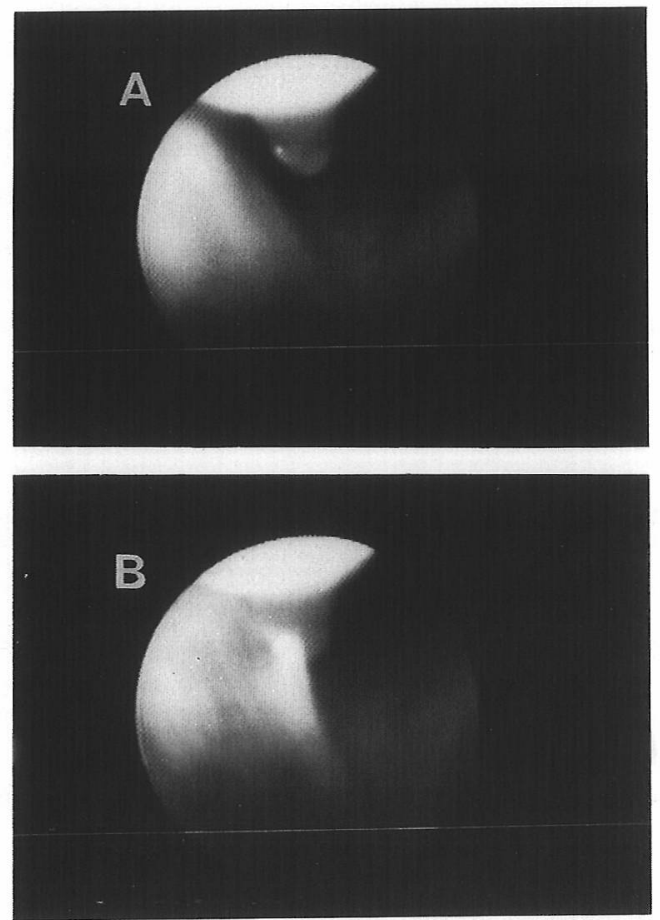

図 2 正常声帯粘膜の吸引直前 $(A)$ と吸引直後 $(B)$ の ビデオ画像. 両面像間の時間差は約 $30 \mathrm{~ms}$ で ある。
引チップの先は盲端で先端近くに径 $1 \mathrm{~mm}$ の側 ロが開いている，声帯組織を垂直に吸引するた めに，側口をファイバースコープの可動方向に 向けて固定した.ファイバースコープはビデオ カメラ（ヒタチ $\mathrm{DK}-5050 ）$ と録画装置（ソニ - VO-5800) に接続した.

被検者の鼻腔，咽喉頭粘膜に表面麻酔を施 し，ファイバースコープを経鼻的に喉頭に挿入 した，声帯遊離縁の組織に吸引チップの側口を 向け，徐々に吸引チップを組織に近づけ，吸引 した，被検者には安静呼吸を指示し，少なくと も 3 度以上，吸引を行なってその状態をビデオ 録画した。吸引時に声帯の内外転運動が少ない 画像を選び，吸引直前と吸引直後の画像から声 帯組織が吸引された距離を計測した。画像はビ デオプリンター（ヒタチ VY-100) によりプリ ントアウトした，図 2 は声帯の正常粘膜が吸引 される直前と直後のビデオ画像である．この 2 画像を図 3 のごとく重㸚合わせ，粘膜組織の移 動距離とスコープの視野の大きさから吸引距離 を求めた。

吸引距離とスティフネスの関係を求めるため, 吸引チップからの距離に対する吸引力を予め測 定した。 その結果, 図 4 に示すごとく, 吸引力 は径 $3 \mathrm{~mm}$ の円内に集中し，ほぼ距離の1.8乗

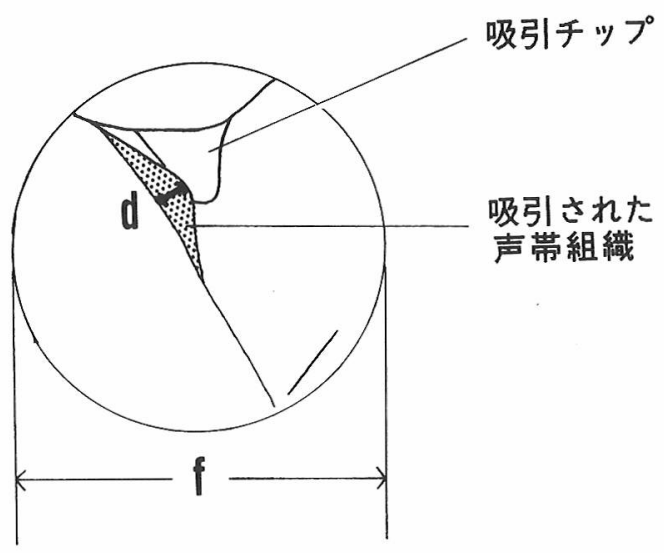

図 3 吸引直前の画像(図 $2 \mathrm{~A}$ ) と直後の画像 (図 $2 \mathrm{~B}$ ) との重称合わせ．スコープの視野の大きさ $(f)$ 之粘膜組織の移動距離 (d) 加ら実際の吸引距離 を求める. 
に逆比例して小さくなった. 声带が理想的な弾 性体であるとみなすと，距離と吸引力の関係式 から吸引距離 $(\mathrm{D})$ とスティフネス $(\mathrm{S})$ の関係は,

$$
\mathrm{S}=1.61 / \mathrm{D}^{2.8}
$$

となった。 この式を用いて，吸引距離からステ イフネスを算出した.

\section{測定結果}

正常者と種々の声带病変を有する患者の測定 結果を表 1 亿示す。病変が声帯の一部に限局し た例では病変の中央部と病変のない声带膜様部 について測定した。正常者の声帯膜様部のステ ィフネスは3〜 $4 \mathrm{~g} / \mathrm{cm}$ の值であった. 声帯溝症 では，溝部で $20 \mathrm{~g} / \mathrm{cm}$ 以上の高いスティフネ スを示し，溝のない粘膜であスティフネスが正 常より高かった. ラインケ浮腫例では正常者と 明かな違いはなかった。喉頭外傷の瘢痕部は著 明に高いスティフネスであり，瘢痕のない粘膜

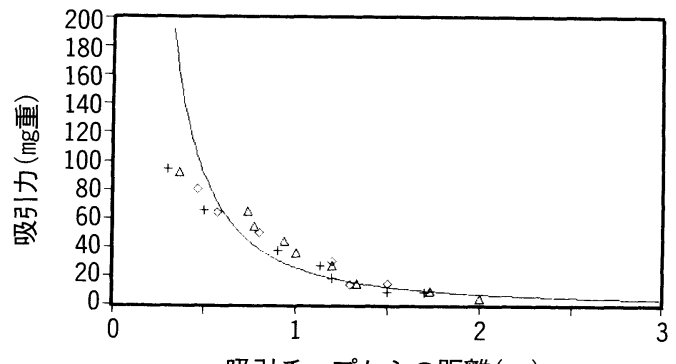

吸引チップからの距離 $(\mathrm{mm})$

図4 吸引距離と吸引力との関係. 図中の $\triangle,+, \diamond$ は各々直径 $3 \mathrm{~mm}, 5 \mathrm{~mm}, 7 \mathrm{~mm}$ の円内に加 る力を示す.
は正常者と同様の值であった。声門癌 2 例では, いずれも，病変部で $20 \mathrm{~g} / \mathrm{cm}$ 以上の高いステ イフネスであった。癌浸潤のない粘膜では正常 よりやや高いスティフネスであった。

\section{考按}

1. ファイバースコープ下吸引法によるステ イフネス測定の利点と問題点

本法はファイバースコープ下に声帯病変部の 吸引距離をビデオ画像で求めてスティフネスを 算出する方法であり, 癌・瘢痕・声带溝の各病 変部の測定結果は著明に高い值を示した。本法 の利点は, ファイバースコープ下で病変の位置 が確認でき，比較的狭い範囲のスティフネスが 測定できることである。更に，喉頭粘膜の表面 麻酔を要するのみで外来診察時にも容易に施行 できることは，臨床的に極めて有用であると考 えられる。乙れらの利点は今まで報告された スティフネスの測定法1) 6) にはなかったもので ある。

本法の問題点としては，まず，声帯組織の吸 引距離が時に测定しにくいことが挙げられる。 すなわち，声帯遊離縁の病変部が吸引チップの 側口に向かって垂直に吸引される場合は容易に 測定できるが，斜めに吸引されると原理的にも 画像を分析する上でも吸引距離は測れない。 ま た，声帯の内外転運動が声帯組織の吸引に重な ると誤差が生じる恐れがある，経験的には，十 分に表面麻酔を施して喉頭の反射的運動を抑え

表 1 正常者と患者の吸引距離とスティフネス

\begin{tabular}{|c|c|c|c|c|c|c|}
\hline & 疾 患 名 & 年齢 & 性 & 測 定 部 位 & $\begin{array}{c}\text { 吸引距離 } \\
(\mathrm{mm})\end{array}$ & \begin{tabular}{|c} 
スティフネス \\
$(\mathrm{g} / \mathrm{cm})$
\end{tabular} \\
\hline \multirow[t]{2}{*}{1} & 正 常 者 & 58 & 男 & 右声带膜様部中央 & 0.74 & 3.7 \\
\hline & & & & 右声帯膜様部後部 & 0.76 & 3.4 \\
\hline \multirow[t]{2}{*}{2} & 声帯 溝 症 & 61 & 男 & 右 声 帯 溝 部 & 0.33 & $20<$ \\
\hline & & & & 右声带健常部 & 0.60 & 6.7 \\
\hline 3 & ラインケ浮腫 & 37 & 男 & 右声帯浮腫部 & 0.79 & 3.1 \\
\hline \multirow[t]{2}{*}{4} & 喉 頭 外 傷 & 23 & 女 & 右 声 帯瘏痕部 & 0.41 & 19.7 \\
\hline & & & & 右声帯健常部 & 0.74 & 3.7 \\
\hline \multirow[t]{2}{*}{5} & 声 門 癌 Tlb & 62 & 男 & 左声带病変部 & 0.32 & $20<$ \\
\hline & & & & 左声帯健常部 & 0.65 & 5.4 \\
\hline 6 & 声 門 癌 T3 & 58 & 男 & 右声帯病変部 & 0.33 & $20<$ \\
\hline
\end{tabular}


た上で安静呼吸位で吸引方向を確認しつつ極め てゆっくりと病変部に近づければ，ほとんど問 題なく測定できた.

次の問題点は，吸引距離とスティフネスの関 係が明確ではないととである。本法では声带組 織を弾性定数一定の理想的な弾性体とみなして 吸引距離からスティフネスを算出したが，摘出 喉頭の実験では声带の弾性定数は負荷が大きい ほよ゙増加する傾向がある1～3). また, 声帯病変の 弾性体としての特徴はほとんど研究されていな い. 従って，本法で求めたスティフネスは必ず しも正確とはいえず，基礎的研究により吸引距 離とスティフネスの関係を確立する必要がある. ただし，本研究の测定結果では高いスティフネ スを有する病変部は明かに正常部より高い值を 示し，本法の測定䛊差は臨床的には余り問題に ならないと考えられる。

\section{2. スティフネス测定の臨床的意義}

一部の喉頭疾患で見られる高スティフネスの 病変は音声障害の主要な原因の一つである。従 って，音声障害患者に対して声带病変のスティ フネスを测定するととは音声障害の原因を解明 するために重要である。また，高いスティフネ スを特徴とする癌病変や痽痕組織の程度と進展 部位を診断するためにもスティフネスの検査が 有用である.

空気力学的研究によると ${ }^{78)}$, 声門癌などの 高スティフネス病変では発声時に声門下圧が高 く，高スティフネス病変の鑑別に役立つ可能性 がある，喉頭ストロボスコープ検査では声門癌 や声带瘏痕の病変部で声帯振動や粘膜波動が久 如するととは周知の事実であり ${ }^{910)}$ ， スティフ ネスを間接的に評価する所見として有用である. しかし，声門下王は他病変でも高くなることが 多い、また，ストロボスコープ検查では主な 振動部位である声帯膜様部付近の病变に限られ る. 従って，乙れらの測定や検査で声带病変の スティフネスが十分に評価できるとは言えず， より直接的な测定法が望まれる。本法のファイ バースコープ下吸引法は前述のごとく吸引距離
からスティフネスを算出でき，直接的なスティ フネス測定法として臨床的に意義が大きい検査 と考えられる.

\section{まとめ}

1. ファイバースコープの鉗子チャンネルに 吸引チップを装着し, 声帯病変の吸引距離より スティフネスを测定する方法を開発した．この 方法で種々の声帯病変のスティフネスを测定し た.

2. 正常な声帯膜様部のスティフネスは3〜4 $\mathrm{g} / \mathrm{cm}$ であった。癌, 瘢痕, 声带溝の病変部で はすべて正常より著明に高いスティフネスを示 した。

3. ファイバースコープ下吸引法によるステ ィフネスの測定は外来診察時に施行でき，癌や 㓔痕などの高スティフネス病変の程度と部位を 評価するのに有用な臨床検査法であると考えら れた。

本論文の耍旨は第51回耳鼻咽喉科臨床学会（1989年 7 月，名山到）で㥕就した。

\section{参考文献}

1）金子敏郎, 浅野 尚, 三浦徹蔵, 他 : 声帯の Biomechanics, Stiffness を中心として. 耳鼻臨床 64 増 : 1229 1235, 1971.

2 ) 平野 実: 音声外科の基礎と臨床. 耳鼻 21 補 $1: 239 \sim 442,1975$.

3 ）横山哲夫, 古川睦之, 平野 実: 人および犬声帯 の構造とスチィフネス. 長崎大工部研報 $10: 75$ 〜82, 1977.

4 ）金子敏郎, 浅野 尚, 三浦徹蔵, 他：声带の Biomechanics, Damping Ratio 中心として.日 気食会報 $25: 133 \sim 138,1974$.

5 ）一色信彦：喉頭機能外科, とくに経皮的アプロー チ. 京大耳鼻科同空会, 1977 .

6 ）斎藤成司 : 発声機構の基礎的研究および喉頭内腔 への臨床的アプローチ. 耳鼻 23 補 $1: 171 \sim 384$, 1977.

7) Tanaka S and Gould WJ : Vocal efficiency and aerodynamic aspects in voice disorders. Ann Otol Rhinol Laryngol $95: 29 \sim 33,1985$.

8 ) Schutte HK : The efficiency of voice production. 
pp 1 188, Kemper, Groningen, 1981.

9 ) Schönhärl E : Die Srtoboskopie in die Praktischen Laryngologie. pp 1 115, Georg Thieme Verlay, Stuttgart, 1960.

10）平野 実：声帯の振動に関する検査，2.喉頭ス卜 ロボスコピー。声の検査法（日本音声言語医学会 編). 87〜 103頁, 医歯薬出版, 東京, 1979.
原稿受付 : 平成元年 8 月 28 日 原稿採択：平成元年 9 月 25 日 別刷請求先 : 田中信三 于 830 久留米市旭町 67

久留米大学医学部耳鼻咽喉科学教室) 